\title{
An Aspect of Kumbh Mela Massive Gathering and COVID-19
}

\author{
Sayed A. Quadri ${ }^{1}$ (D) Prasad R. Padala ${ }^{2,3}$
}

Accepted: 15 March 2021 / Published online: 29 March 2021

(C) The Author(s), under exclusive licence to Springer Nature Switzerland AG 2021

\begin{abstract}
Purpose of Review Kumbh Mela, a religious gathering of Hindus held in India, is the largest massive gathering event in the world. The COVID-19 pandemic is an unprecedented healthcare crisis in recent times with effects reverberating in all spheres of human lives. India has registered the second highest number of COVID-19 cases. This paper aims to dwell in the religious and social background of Kumbh Mela massive gathering, as well as the ritualistic practices that could potentially entail public health risks in the current situation. It also aims to identify possible preparatory and interventional measures to evade such risks.

Recent Findings In recent years, the increase in the number of people attending the Kumbh Mela has been phenomenal. Congregants are put up at the holy sites for several days. The sheer number of people assembling at the religious venues poses a great challenge to manage the crowds, to cater to the requirements of basic amenities, and to meet their healthcare needs. Some of the ritualistic practices could heighten the risk for transmission of respiratory pathogens. The COVID-19 pandemic has escalated over the past few months in India. The pandemic is expected to sustain its tempo in India throughout the foreseeable future. Organization of the forthcoming Kumbh Mela needs meticulous planning.

Summary Kumbh Mela is a Hindu religious gathering at the banks of India's rivers, held periodically. It witnesses assembly of huge numbers of people and has the potential to amplify the COVID-19 pandemic in India; this could overwhelm the healthcare system.
\end{abstract}

Keywords COVID-19 $\cdot$ Kumbh Mela $\cdot$ Mass gatherings $\cdot$ Hinduism $\cdot$ Religion religious congregations $\cdot$ Public health

\section{Introduction}

"Religion is the opiate of the masses", proclaimed the famous German economist and philosopher Karl Marx in 1843 AD, in his treatise "Critique of Hegel's Philosophy of Right". The metaphor used in a different context though, by Marx, aptly reflects humankind's unassailable affinity towards religion. A large majority of the world

This article is part of the Topical Collection on Massive Gathering Events and COVID-19

Sayed A. Quadri

microquadri@gmail.com

1 Division of Microbiology and Immunology, Department of Biomedical Sciences, College of Medicine, King Faisal University, Al-Ahsa, Eastern Province, Kingdom of Saudi Arabia

2 Geriatric Research Education, and Clinical Center, Central Arkansas Veterans, Healthcare System (CAVHS), Little Rock, AR, USA

3 Department of Psychiatry, University of Arkansas for Medical Sciences (UAMS), Little Rock, AR, USA population follows and believes in religion [1]. The impact of religion and its practice on health has intrigued several investigators. Religion and spirituality could have salutary impact on health [2]. There are strong indications that they may have positive influence on physical and mental well-being [3]. While the optimism and mutual love fostered by religion and spirituality are critical in coping with adversities [3], some of the rituals and faith-based decisions might help the spread of pandemics unintentionally.

Hinduism is an ancient religion followed by over 1.1 billion people worldwide. This constitutes more than $15 \%$ of humanity [4]. A predominant majority of Hindus live in South Asia. The region also has most of the Hindu sacred sites. They form a majority in three countries: India, Nepal, and Mauritius [5]. Hindu diaspora is found across the globe. India, the second most populous country in the world, has the single largest Hindu population of the world: around a billion people which constitute almost $80 \%$ of the total population of the country [6]. It is important thus to focus on Hindu events that have potential to worsen the current pandemic owing to the sheer number of participants in such events. 
Religious events entailing assembly of large numbers of practitioners of the religion are an important ritualistic feature of all major world major religions. Hinduism is no exception to it. Massive gathering event (MGE) is defined as an assembly of a large number of people attending an organized event within a defined space [7]. There are huge public health implications of MGE [8]. Public health concerns at these events would include a range of health issues: transmission of water, food, air, and vector-borne communicable diseases, exacerbation of non-communicable diseases, stampedes, accidents, worsening of mental health problems, and health consequences of alcohol and substance abuse [9].

The Severe Acute Respiratory Syndrome Coronavirus-2 (SARS-CoV-2) spread across the international borders quickly after its emergence in China in December 2019. More than 36 million people have been infected and over a million people have succumbed to the virus hitherto [10]. The virus is transmitted by respiratory route through droplets. Other possible routes of transmission could include contact, airborne, and feco-oral transmission. With an average basic reproduction rate (R0) of 2.2 , it could spread rapidly $[11,12]$. Corona virus disease (COVID-19) can have a wide spectrum of clinical disease from asymptomatic infections to severe pulmonary and systemic immune-modulated inflammatory disease [13]. Older people with pre-existing co-morbidities are at an increased risk of developing severe disease and death [14]. The key in breaking the chain of transmission and protection from acquiring infection is implementing prevention measures both at individual and community levels. Social distancing, wearing face masks, hand hygiene, quarantine, and isolation of the sick people are the recommended measures to protect people from acquiring the infection [15].

Religious congregations have been associated with COVID-19 outbreaks [16]. The spread and devastation caused by COVID-19 pandemic has been unprecedented in modern human history. India has been one of the hardest hit countries. It is therefore prudent to revisit humanity's largest gathering, the Kumbh Mela. This could help us recalibrate our preparedness and response in order to avert any large-scale adverse public health consequences. This paper attempts to analyze the religious and social context of Kumbh Mela as a Hindu mega festival and its ritualistic practices. The likelihood of a spike in COVID-19 cases and its adverse impact on healthcare in India is also assessed.

\section{Hinduism and the Religious Significance of Pilgrimage in Hinduism}

Etymologically, the word Hindu is derived from the Sanskrit word Sindhu, which is the Sanskrit name of the Indus River. The pre-Islamic Persians are thought to have used the word Hindu for the first time as they pronounced letter ' $h$ ' for the letter 's' [17]. Apparently, the word was used for people residing beyond Indus River. Unlike the monotheistic Abrahamic religions, Hinduism is not a rigid, orthodox, organized religion but rather a loose and heterogeneous framework of belief system with disparate rituals and practices. However, it has certain core beliefs around which the faith revolves. This includes the concept of rebirth or samsara. According to this belief, the next rebirth could be in any living form and is determined by the actions, the karma, committed in the current life. On the other hand, dharma is defined as an entire gamut of good practices in all dimensions of life. The ultimate aim is to escape the cycle of rebirths and attain salvation referred as moksha. An easy approach towards attaining moksha would be to renounce or abandon the mundane life. This is called sanyasa. The Hindu religion is pantheistic with multiple Gods and Goddesses. The central divine figures are the Hindu trinity of Brahma, Vishnu, and Shiva, each having distinct and defined domains. Besides them, other Gods or human reincarnate of Gods are worshipped.

A striking feature of Hindu religious practices is undertaking pilgrimages to sacred sites and performing rituals there for varied purposes that include getting rid of sins and attaining moksha, thanksgiving, seeking worldly favors, proximity to the divine, pursuit of spiritual solace, or simply fulfilling religious obligations. Visitation to Hindu sacred sites, known as tirtha yatra, is an integral part of the faith. Singh and Haigh classify the tirthas into three types based on their topography: water bodies including rivers, shrines dedicated to particular deity, and holy lands called kshetras [18]. A uniquely distinct characteristic of Hindu religion is identifying or associating divinity with nature. The earth is venerated as Goddess Mother or matrubhoomi. Mountain ranges, especially the Himalayas, are believed to be the abode of Gods. Rivers are considered sacred in Hinduism and are seen as the personification of deities and have great mythological significance [19]. India is crisscrossed by several river systems, the major being: Indus, Ganges and Brahmaputra and their tributaries in the north, Narmada and its tributaries in central India and the Krishna and Cauvery and their tributaries in the peninsular India. Ganges is the most sacred river and is associated with Shiva [19]. People undertake pilgrimage on specific days of the Hindu calendar. Taking a bath in rivers is believed to cleanse oneself of the sins and attain moksha [17]. Some of the major Hindu tirthas are rivers or water bodies where sacred immersion on auspicious days is believed to serve several spiritual purposes [18].

\section{Kumbh Mela: Religious and Socio-cultural Aspects}

Kumbh Mela is a massive congregation of Hindu devotees and sages at the banks of rivers on certain auspicious days in the 
Hindu calendar. The term in Sanskrit literally means 'festival of pitcher'. According to Hindu sacred scriptures, the puranas, a fight arose between the Gods and the demons for possession of a pitcher containing the elixir of life. During the ensuing struggle, a few drops of the elixir were spilled on earth. The elixir dropped at four places which became the venues for Kumbh Mela. The fight occurred for 12 divine days which are equated with 12 worldly years. Therefore, four Kumbh Mela are organized at four different places in a cycle of 12 years [20]. The Kumbh Mela are observed at Prayagraj in the state of Uttar Pradesh and at Haridwar in Uttarakhand state, both on the banks of the Ganges river, at Ujjain in Madhya Pradesh state on the bank of the Shipra river and at Nashik in Maharashtra state on the banks of the Godavari river [21]. Whereas Kumbh Mela is held every 12 years at Ujjain and Nashik and at Prayagraj and Haridwar, they are held twice during the same period. At the latter two places, the Mela is organized after 6 years as Ardh Kumbh Mela and after 12 years as Purna Kumbh Mela. In fact, every year in the month of Magh of the Hindu calendar (mid-January to midFebruary), a relatively smaller fair is celebrated at Prayagraj. Even this gathering, called the Magh Mela, could be attended by several hundreds of thousands people [22].

The Kumbh Mela at Prayagraj is the largest of all and is attended by highest number of devotees, estimated to be around 120 million in 2013 [23]. This is the world's largest gathering of humanity on earth [24, 25••]. More importance is attached to the Prayagraj Kumbh Mela as the venue for this congregation has special significance. It is conducted at Triveni Sangam, at the confluence of three rivers: Ganges, Yamuna, and the mythical Saraswati. The local government, volunteers, and non-governmental agencies coordinate to make such a massive event possible. In 2013 alone, the collective efforts set up 11 sectors with 55 camp clusters, providing round-the-clock first aid, ambulance, pharmacy, sanitation, food and water distribution cooking fuel, and other services. One estimate shows that $550 \mathrm{~km}$ of pipelines was operated by 42 pumps to provide potable water for the MGE.

In the year 2017, the United Nations Educational, Scientific and Cultural Organization has listed Kumbh Mela as the intangible cultural heritage of humanity [26]. Kumbh Mela truly reflects the socio-cultural milieu of Hinduism. It attracts people from all strata of the society and demographically diverse population groups [27]. Commoners, elites, politicians, sages, ascetics, preachers, priests, and social workers are all on the ground for different purposes [21].

\section{Rituals at Kumbh Mela and Their Health Implications}

The religiosity at Kumbh Mela is marked by a flurry of actionpacked events that are stretched through a period of 6-7 weeks. The faithful are steeped in devotion and aspire to complete the rituals as prescribed. Pilgrims arrive and leave at different points of time during this period but the congregation swells to the brim on the auspicious bathing day. Temporary tents are put up along the sandy banks of Ganges River in Prayagraj to house the pilgrims. This township comes up with all civic and administrative amenities such as food provision, potable water supply, sanitation, waste and sewage disposal, security, guidance and personal assistance, and healthcare facilities [28].

Ritualistic practices at the Kumbh include offering Aarti: communal singing of hymns in praise of Gods at the riverbank, Deep Dan: lighting small earthen lamps at sacred places, Snan: taking holy bath by immersing in the river, Yajnas: chanting of mantras around the sacred fire by the priests, Kirtan: devotional singing, Darshan: meeting and seeking blessings from the sages, Mahaprasad and Langar: serving of celebratory feast, and Pravachana: religious sermons and discussions. While the Aarti, Kirtan, Darshan, Langar, and the Pravachana could be held regularly, the Snan, Deep Dan, and Yajnas are performed on a specific day, place, and time [29]. All the events entail congregations of people in large numbers at specific places. However, the biggest assembly of people is during the observation of the much-awaited and revered Snan, as it is believed that the river water turns sacred elixir at the auspicious time, and by immersing in the river water, one can attain moksha. On the designated auspicious day, the Hindu holy men, the Sadhus, perform the bathing ritual first and the rest then follow in hordes later. Millions of men and women take a dip in the river in a matter of a few hours. The act is replete with religious fervor, sometimes reaching to the extent of frenzy. In the commotion, people jostle to complete the ritual.

Public health risks of the massive gathering of people are enormous and are of wide dimensions [9]. In the case of Kumbh Mela, the unique ritual practice of Snan poses additional health peril besides the risks involved in any MGE. Mass bathing in the river has been documented to increase the bacterial load of river water [23]. Water could be contaminated by skin, mucosal, and intestinal microbes carried by pilgrims. Historical cholera outbreaks have been reported at the Kumbh Mela in the 19th century [30]. Diarrhea/dysentery, typhoid, and other water-borne diseases are a potential risk.

Impracticality of maintaining social distancing in such a gigantic mass of people is clearly evident. Close physical contact facilitates easy and rapid spread of respiratory pathogens. Therefore not surprisingly, upper respiratory tract infections (URTI) were reported to be the leading cause of illness among the pilgrims in the Kumbh Mela of 2013. URTI accounted for as many as $70 \%$ of illness among the pilgrims [31]. The increased occurrence of respiratory infections 2 days after the mass bathing ritual reinforces the notion of Snan as a public health risk event [32••]. Elsewhere too, MGE of religious or 
secular nature have also shown the same trend [33, 34•, 35]. Many pilgrims are older and weak and have co-existing morbidities. Physical exertion, dehydration, and inadequate sleep are not uncommon among the pilgrims. This could augment propensity to develop complications. Mass of pilgrims at the Bank of Ganges, Prayagraj, performing Snan during Maha Kumbh Mela (Courtesy Alessandro Longhi licensed under CC BY-NC-ND 2.0)

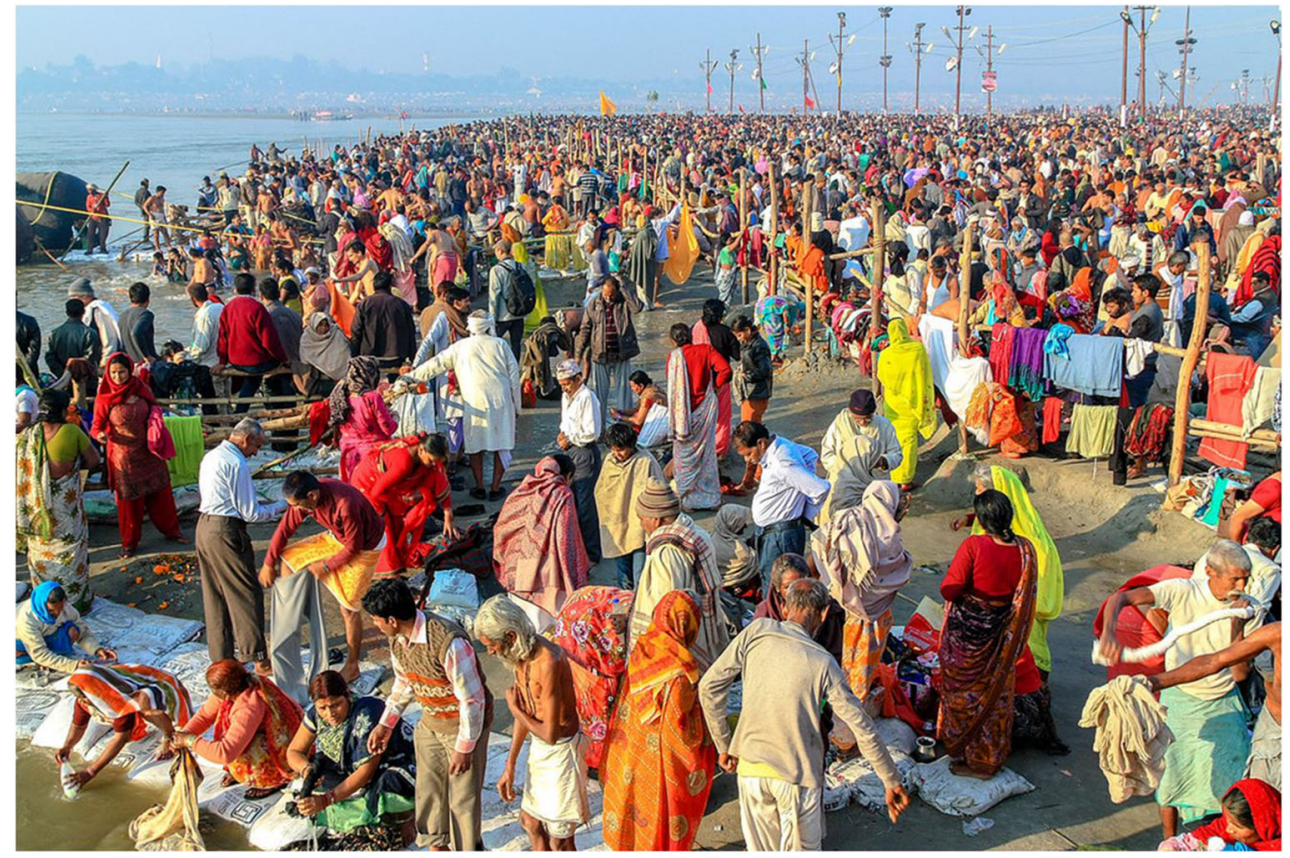

\section{Dynamics of COVID-19 Pandemic in India}

SARS-CoV-2 entered India on January 30, 2020 [36]. In order to contain the virus spread, a nationwide lockdown was imposed on March 24, 2020. The country was successful in limiting the number of cases initially with a slew of preventive and containment measures [37]. However, due to economic and social reasons, the lockdown was gradually eased. Millions of stranded migrant workers left industrialized western regions of the country to northern and eastern countryside once the domestic travel restriction was waived off. The trajectory of COVID-19 cases has been rapidly moving upward since the month of June 2020. As of October 25, 2020, India has reported 7,864,811 cases and 118,534 deaths due to COVID-19 [38].

India is the second largest populated country in the world. It has a federal system of governance and there are striking differences in the areas of literacy and income levels as well as demographic and population density among different states. There is a considerable income and living standard disparity in every town and city. With such a huge population and crowded living conditions in a major part of the country, concerns were raised in the initial phase of the pandemic; if strong and decisive measures are not taken, the disease could ravage the country and extract an immense toll both in terms of its economic and healthcare impact. The pandemic grew slowly in its initial phase. However, with impatience brewing due to restriction placed on public movement and its economic impact, the government was compelled to lift these restrictions. Cases started surging ahead in the western states of Maharashtra and Gujarat, and soon, other states had to face the onslaught. Currently, the virus is entrenched across India with new infections still occurring in significant numbers. There is a growing weariness among public to practice protective measures such as wearing masks, maintaining social distancing, and using hand sanitizers. The possibility of COVID-19 disease occurring in waves cannot be ruled out, as yet a large proportion of Indians remain susceptible. Complacency could prove sinister if a sustained vigilance is not maintained.

\section{The Kumbh Mela in COVID-19 Times: Public Health Risks and Preparedness}

MGE like the Kumbh Mela, at this juncture, has the potential to be a public health risk of immense adverse consequences and could overwhelm the healthcare system. It could also prove to be a super spreader event with a further nationwide 
surge in COVID-19 cases, as infected individuals might carry the virus to their homes. Recent events have demonstrated that large congregations could turn out to be dispersal hubs of COVID-19 [16].

The dates for the 2021 Kumbh Mela have been announced to start on January 14th and to culminate on April 27th. Various snan/bathing dates have been announced with four major snans also known as shahi snan scheduled between March and April. Although there seems to be no flexibility in the dates of the event, the apex body of the Akhadas, Akhil Bharatiya Akhada Parishad, has shown some willingness to hold the Kumbh Mela in a restrictive manner.

Keeping the public health risks associated with large religious congregations in view, and in the light of growing COVID-19 cases in India, social, administrative, and healthcare measures must be instituted. We recommend the following measures to preclude any possibility of a health crisis spinning out of control at the forthcoming Kumbh Mela.

1. Restrict the number of participants in Kumbh Mela in 2021

1. Introduce an online pilgrim registration system. Ensure that only the registered pilgrims enter the holy precincts.

2. Employ the GPS tracking system of the pilgrims.

3. Employ drones to monitor the public movement.

4. Increase the use of infographics and short information videos before and during the mela.

5. Devise a COVID-19 rapid response and triage strategy.

6. Work with religious leaders to promote public health messages of physical distancing, wearing a mask, and washing hands regularly

7. Provide pilgrims alternate sites for Magh Mela in various parts of India.

8. Keep the older population and the sick out of the Mela.

9. Have a robust screening in place at various entrance points of the Mela.

10. Invest heavily in hand-sanitizing stations peppered throughout the Mela.

11. Put in place infrastructure for quarantining the sick.

12. Scale up the healthcare infrastructure and resources to meet any large-scale outbreak.

\section{Conclusion}

Events such as religious congregations could have public health repercussions that need serious consideration. The public health implications are not only limited to the place itself but could engulf larger geographical areas and could have far reaching consequences. In recent years, these gatherings have seen an unprecedented increase in number of people attending them. Kumbh mela is the largest assembly of human beings and is held in India: the second most populous country in the world. In the prevailing situation of an economic, social, and healthcare crisis due to the COVID-19 pandemic, it is essential that a realization of potential public health implications of Kumbh Mela be made. The rituals at this MGE are to be understood in their potential to be a public health threat. Crowds could become unruly and disorderly in their religious fervor to fulfill these rituals. A slew of preventive measures need to be taken to obviate the public health risks at Kumbh Mela.

\section{Declarations}

Conflict of Interest Sayed A. Quadri and Prasad R Padala declare that they have no conflict of interest

Human and Animal Rights and Informed Consent This article does not contain any studies with human or animal subjects performed by any of the authors.

\section{References}

Papers of particular interest, published recently, have been highlighted as:

- Of importance

•. Of major importance

1. Sherwood H (2018) Religion: why faith is becoming more and more popular. The Guardian

2. Levin JS. Religion and health: is there an association, is it valid, and is it causal? Soc Sci Med. 1994;38:1475-82.

3. Koenig HG. Religion, spirituality, and health: the research and clinical implications. ISRN Psychiatry. 2012;2012:1-33.

4. World's largest religion by population is still Christianity | Pew Research Center. https://www.pewresearch.org/fact-tank/2017/04/ 05/christians-remain-worlds-largest-religious-group-but-they-aredeclining-in-europe/. Accessed 7 Apr 2020

5. NW 1615 L. St, Washington S 800, Inquiries D 20036 U-419-4300 | M-419-4349 | F-419-4372 | M (2012) Hindus. Pew Res. Cent. Relig. Public Life Proj.

6. author2 (2015) Census 2010. In: Gen. Auth. Stat. https://www.stats. gov.sa/en/73. Accessed 31 May 2020

7. Zeitz KM, Tan HM, Grief M, Couns P, Zeitz CJ. Crowd behavior at mass gatherings: a literature review. Prehospital Disaster Med. 2009;24:32-8.

8. Executive Board 130 (2012) Global mass gatherings: implications and opportunities for global health security: report by the Secretariat.

9. Memish ZA, Steffen R, White P, Dar O, Azhar EI, Sharma A, et al. Mass gatherings medicine: public health issues arising from mass gathering religious and sporting events. The Lancet. 2019;393: 2073-84.

10. Coronavirus Disease (COVID-19) - events as they happen. https:// www.who.int/emergencies/diseases/novel-coronavirus-2019/ events-as-they-happen. Accessed 26 Sep 2020

11. Cheng ZJ, Shan J. 2019 Novel coronavirus: where we are and what we know. Infection. 2020;48:155-63. 
12. Jin Y, Yang H, Ji W, Wu W, Chen S, Zhang W, et al. Virology, epidemiology, pathogenesis, and control of COVID-19. Viruses. 2020;12. https://doi.org/10.3390/v12040372.

13. Ye Q, Wang B, Mao J. The pathogenesis and treatment of the 'Cytokine Storm' in COVID-19. J Infect. 2020;80:607-13.

14. Bassendine MF, Bridge SH, McCaughan GW, Gorrell MD. COVID-19 and comorbidities: a role for dipeptidyl peptidase 4 (DPP4) in disease severity? J Diabetes. 2020;12:649-58.

15. Wilder-Smith A, Freedman DO (2020) Isolation, quarantine, social distancing and community containment: pivotal role for old-style public health measures in the novel coronavirus (2019-nCoV) outbreak. J Travel Med 27:taaa020

16. Quadri SA. COVID-19 and religious congregations: implications for spread of novel pathogens. Int J Infect Dis. 2020;96:219-21.

17. Flood G. An introduction to Hinduism: Cambridge University Press; 1996.

18. Singh RPB, Haigh MJ (2015) Hindu Pilgrimages: the contemporary scene. In: Brunn SD (ed) Chang. World Relig. Map. Springer Netherlands, Dordrecht, pp 783-801

19. Agoramoorthy G. Sacred rivers: their spiritual significance in Hindu Religion. J Relig Health. 2015;54:1080-90.

20. Divya and Bhavya Kumbh. In: PrayagrajKumbh. https://kumbh. gov.in/. Accessed 13 Jun 2020

21. Kumbh Mela| Significance, Festival, \& History. In: Encycl. Br. https://www.britannica.com/topic/Kumbh-Mela. Accessed 22 Jul 2020

22. Tewari S, Khan S, Hopkins N, Srinivasan N, Reicher S. Participation in Mass gatherings can benefit well-being: longitudinal and control data from a North Indian Hindu Pilgrimage Event. PLoS ONE. 2012;7:e47291.

23. Jani K, Dhotre D, Bandal J, Shouche Y, Suryavanshi M, Rale V, et al. World's largest mass bathing event influences the bacterial communities of Godavari, a Holy River of India. Microb Ecol. 2018;76:706-18.

24. Vortmann M, Balsari S, Holman SR, Greenough PG. Water, sanitation, and hygiene at the world's largest mass gathering. Curr Infect Dis Rep. 2015;17:5.

25.• Dwivedi S, Cariappa MP. Mass-gathering events: the public health challenge of the Kumbh Mela 2013. Prehospital Disaster Med. 2015;30:621-4 Dwivedi et al described the experience of 2013 Kumbh Mela at Prayagraj highlighting the public health dangers lurking in such a massive gathering event. This is particularly relevant in the current situation.

26. UNESCO - Kumbh Mela. https://ich.unesco.org/en/lists. Accessed $26 \mathrm{Jul} 2020$
27. Barnett I, Khanna T, Onnela J-P. Social and spatial clustering of people at humanity's largest gathering. PLOS ONE. 2016;11: e0156794.

28. Balsari S, Greenough PG, Kazi D, Heerboth A, Dwivedi S, Leaning J. Public health aspects of the world's largest mass gathering: the 2013 Kumbh Mela in Allahabad, India. J Public Health Policy. 2016;37:411-27.

29. Kumbh Mela - Everything you need to know about. In: Travel Co. India Tour Oper. India Colourful Indian Holidays. https:// colourfulindianholidays.com/fair-festivals/kumbh-mela/. Accessed 24 Sep 2020

30. Herbert $\mathrm{H}$. The natural history of Hardwar fair cholera outbreaks. Indian Med Gaz. 1895;30:298-300.

31. Cariappa MP, Singh BP, Mahen A, Bansal AS. Kumbh Mela 2013: Healthcare for the millions. Med J Armed Forces India. 2015;71: 278-81.

32.• Sridhar S, Gautret P, Brouqui P. A comprehensive review of the Kumbh Mela: identifying risks for spread of infectious diseases. Clin Microbiol Infect. 2015;21:128-33 Sridhar et al described the potential health risks at Kumbh Mela related to social and communal living including sanitation problems such as open air defecation, cooking by burning firewood and overcrowding at religious ceremonies.

33. Memish ZA, Al-Rabeeah AA. Public health management of mass gatherings: the Saudi Arabian experience with MERS-CoV. Bull World Health Organ. 2013;91:899-899A.

34. Hoang V-T, Gautret P. Infectious diseases and mass gatherings. Curr Infect Dis Rep. 2018;20:44 Hoang et al evaluated the occurrence of different infectious diseases in massive gatherings including Haj, Kumbh Mela and other festivals and gatherings.

35. Al-Tawfiq JA, Memish ZA. Mass gatherings and infectious diseases. Infect Dis Clin North Am. 2012;26:725-37.

36. Kakar A, Nundy S. COVID-19 in India. J R Soc Med. 2020;113: 232-3.

37. Mukherjee S. Disparities, desperation, and divisiveness: coping with COVID-19 in India. Psychol Trauma Theory Res Pract Policy. 2020;12:582-4.

38. India: WHO Coronavirus Disease (COVID-19) Dashboard. https:// covid19.who.int. Accessed 25 Oct 2020

Publisher's Note Springer Nature remains neutral with regard to jurisdictional claims in published maps and institutional affiliations. 